\title{
Auxctican Tsiychiatry.
}

UNDER THE DIRECTION OF

R. M. PHELPS, A.M., M.D.,

Rochester, Minn.

With the Following Collaborators:

Martin W. Barr, Chief Phys., Penn. Trainiug S̄chool for Feeble Minded, Elwynu, $\mathrm{Pa}$.

I. W. BlackbURN. Pathologist, Government Hospital for Insane, Washington, $\mathrm{D} . \mathrm{C}$.

E. D. Bondurant, M.D., Asst. Supt., Alabama Insane Hospital, Tusca loosa, Ala.

WM. DRfWry, M.D., Asst. Phys., Central Lunatic Asylum, Peters burg, Va.

B. D. Evans, M.D., Medical Director, State Asylum, Morris Plaina, New Jersey.

Ciarke GapgN, M.D., Supt., Illinois Eastern Hospita1, Kankakee, 111.

F. O. Jackman, M.D., Asst. Phys. \& Pathologist, Hospital for Insane, Mt. Pleasant, Iowa.

J. M. KEniston, M.D., Asst. Phys., Connecticut Hospital for Insane, Middletown, Conn.

Chas. B. MayberRy, M.D., Asst. Phys., State Hospital for Insane, Danville, $\mathrm{Pa}$.

IRvis H. NEFF, M.D, .1sst. Phys., Eastern Michigan Asylum, Pontiac, Mich.

A. B. Richardson, M.D., Supt., Columbus Asylum for Insane, Columbus, Ohio.

H. A. Tomlinson, M.D., Supt., St. Peter State Hospital, St. Peter, Minn. JOHN W. WAUGHOP, Supt., Western Washington Hospital for the In. sane, Fort Steilacooni, Washington.

W. L. WorcestrR, M.D., Asst. Phys., Danvers Lunatic Hospital, Mass.

\section{ORIGINAL STUDIFS AND REPORTS.}

TrainingSchool for Following several years of desultory Nurses, A labama Bryce Main Hospital.

effort at the instruction of attendants, the organization of a Training School for Nurses was effected two years ago. The work has been systematically carried forward to the present time, and the first class, of four young women, received their certificates in June of this year.

The course extends over two years, and is made to embrace the following : 
Ist. Practical instruction in the wards by the supervisor and medical staff, in the methods of caring for the sick and the insane, including the various nursing procedures, surgical nursing and minor surgical dressings and bandaging, giving of baths of all kinds, keeping of bedside notes, charting temperature, etc., demonstrations in allatomy upon the cadarer, a course in massage, dietetics and sick room cookery, etc.

2nd. A recitation to the supervisor each week during nine months of the year, based upon the " Mallual of Nursing," by Weeks, (junior year), or "Nursing," by Miss Hampton, (senior year); also a weekly lecture or demonstration by a member of a medical staff; these lectures covering during the two years elementary anatomy, physiology, hygielle, insanity and nervous diseases, with the care of the insane and of nervous invalids. bacteria, infection, asepsis, disinfection, contagious diseases and their care, surgical nursing, fevers and the nursing of fever cases, emergencies and how to nicet them, and such special topics as seemed from time to time advisable.

3 rd. Practical experience in the several wards of the hospital, including a term of service in the wards for quiet and convalescing patients; the wards for the excited and the disturbed; for the helpless and unclean; the epileptic ward; the reception ward; the sick ward; night duty.

It is thought that the graduates will be competent to take charge of cases in private practice-cases of fever and bodily disease as well as of nervous diseases and insanity. Of the four graduates three have already had the care of cases in private nursing, and have givell satisfaction.

It is expected that some will undertake this work. Those who prefer to remain in the service of the hospital will be retained at increased pay.

The policy thus far pursued has been while encouraging the nurses to undertake and continue the training school work, to use no compulsion, and to require no pledge of an intention to complete the course. Those who lose interest or show incapacity are permitted to discontinue the work at any time. The standard established is high, and the amount of work required quite considerable. As a consequence only a small percentage of those who begin the course will receive certificates. Those, however, who do not complete the two years' course will be of the higher grade only, and possessed of the natural aptitude, intelligence, training and stability of character which should insure success in nursing in any of its departments.

The first junior class consisted of sixteen women and nine men. Of these, none of the men and only four of the wonien received certificates. The second junior class which took up the work last October, included twenty-six women, of which eight have been, after the first year examiuations, passed into 
the senior class. The class to begin in the coming October will consist of about fifteen women and a few of the male nurses.

Looking backward over the work of our first two years, we say unhesitatingly that the results thus far obtained fully justify the needed expenditure of time and energy. While few are graduated, all, even the few who have not joined the classes, receive a great deal of instruction, the standard of nursing is raised, the general ward work is better done, the newly admitted patients are better cared for, the sick are better cared for, the clinical records are improved by the addition of the nurses' daily notes, charts, etc. The relations between patients and nurses are more satisfactory. The nurses themselves receive a training which offers them the opportunity of successful work in private nursing, and which will be of service in any walk of life which may be followed. And finally the reflex influence of the training and instruction is a beneficial one upon the medical staff, to whom falls the work of preparing the lectures and demonstrations.

E. D. BONDURANT.

\section{NEW'S AND MISCELLANY.}

Report of Commis- The Report of the Committee on Lunsion in runacy. acy of the Board of Public Charities of Pennsylvania.

Pennsylvania for the year ending September 30,1894 , has recently been issued, and while containing much valuable information it is to be regretted that, like its predecessors, its contents are antiquated long before its publication. The mo-t important subject considered in the report is the question of providing relief for the overcrowded hospitals, a question which has required almo-t constant consideration since the formation of the Committee on Lunacy, and one which bas been a constant menace to the safety and well. being, as well as to the success in treatment of the indigent insane of Pennsylvania. On the 3oth of September, 1894, there were in the state hospitals $5,23^{2}$ patients crowded into institutions with with a very liberally estimated capacity of 4.335 , an excess of 897 patients. This excess is increasing at the rate of an average of 184 patients a year. In order to solve this difficult problem new institutions for the insane, of some nature, are necessary, and,"the question which confronts the present legislature is . . what character of new institutions should now be founded and what special classes of the insane should occupy them." To answer this question the following suggestions are made :

(I) Another institution (asylum) for the indigent chronic insane, similar to that at Wernersville. In making this suggestion, however, the committee seems to ignore the fact that, 